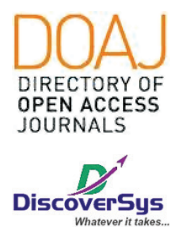

Published by DiscoverSys

\section{Uji efektivitas ekstrak etanol kulit buah naga merah (Hylocereus polyrhizus) terhadap Staphylococcus aureus ATCC 25923 secara in vitro}

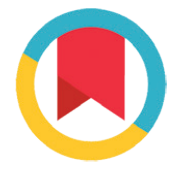

CrossMark

\author{
Anak Agung Bintang Astridwiyanti, ${ }^{1 *}$ Agung Nova Mahendra, ${ }^{2}$ Ni Wayan Sucindra Dewi ${ }^{2}$
}

\section{ABSTRACT}

Introduction: Infectious diseases are still one of the main causes of high morbidity and mortality in tropical Indonesia. One of the causes of this disease is the staphylococcus aureus bacteria. Red dragon fruit peel contains potentially antibacterial compounds such as flavonoid, alkaloid, saponin, tannin dan terpenoid. The purpose of this study is to determine the antibacterial activity of ethanolic extract of red dragon fruit peel against staphylococcus aureus ATCC 25923.

Method: The method used is true experimental post test only control group design. The activity of ethanol extract of red dragon fruit skin was tested in various concentrations (25\%, 50\%, $75 \%$, and $100 \%)$ against staphylococcus aureus ATCC 25923 by measuring the inhibition zone diameter and minimum inhibitory concentration (MIC).
Result: The results of this study show that red dragon fruit peel ethanolic extract has antibacterial activity against staphylococcus aureus ATCC 25923 ith the average diameter of inhibition zone ranging from $8.25 \mathrm{~mm}-12.5 \mathrm{~mm}$. The MIC is obtained at concentration of $25 \%$. Kruskal-Wallis test found a significant comparison with a value of $p=0,000$ ( $p$ value $<0.05$ ). Mann-Whitney test showed that there were significant differences between each concentration, except the concentration of $50 \%$ did not have a significant difference with a concentration of $75 \%$.

Conclusion: The minimum inhibitory concentration (MIC) is produced by extract at a concentration of $25 \%$ and the best inhibitory zone produced by $100 \%$ concentration of red dragon peel ethanol extract.

Keywords: Red dragon peel (hylovereus polyrhizus), ethanolic extract, inhibition zone, MIC, S.aureus

Cite This Article: Astridwiyanti, A.A.B., Mahendra, A.N., Dewi, N.W.S. 2019. Uji efektivitas ekstrak etanol kulit buah naga merah (Hylocereus polyrhizus) terhadap Staphylococcus aureus ATCC 25923 secara in vitro. Intisari Sains Medis 10(3): 482-486. D0I: 10.15562/ism.v10i3.425

\title{
ABSTRAK
}

Latar Belakang: Penyakit infeksi masih menjadi salah satu penyebab utama tingginya angka kesakitan dan kematian di Indonesia yang beriklim tropis. Salah satu penyebab penyakit infeksi ini adalah bakteri staphylococcus aureus. Kandungan kulit buah naga seperti flavonoid, alkaloid, saponin, tannin dan terpenoid merupakan senyawa yang berpotensi sebagai antibakteri. Tujuan penelitian ini untuk mengetahui aktivitas antibakteri dari ekstrak etanol kulit buah naga merah (hylocereus polyrhizus) terhadap pertumbuhan bakteri staphylococcus aureus ATCC 25923.

Metode: Metode yang digunakan adalah true experimental post test only control group design. Aktivitas ekstrak etanol kulit buah naga merah diuji dalam berbagai konsentrasi $(25 \%, 50 \%, 75 \%$, dan 100\%) terhadap staphylococcus aureus ATCC 25923 dengan mengukur diameter zona hambat dan konsentrasi hambat minimal (KHM).

Hasil: Hasil penelitian ini menunjukkan adanya daya hambat ekstrak etanol kulit buah naga merah terhadap staphylococcus aureus ATCC 25923 dengan rereata diameter zona hambat berkisar antara 8,25 mm sampai $12,5 \mathrm{~mm}$. untuk konsentrasi hambat minimal didapatkan pada konsentrasi $25 \%$. Uji Kruskal-Wallis didapatkan perbandingan yang bermakna dengan nilai $p=0,000$ (nilai $p<0,05$ ). Uji Mann-Whitney menunjukkan bahwa terdapat perbedaan yang bermakna antar setiap konsentrasi, kecuali konsentrasi $50 \%$ tidak memiliki perbedaan bermakna dengan konsentrasi $75 \%$.

Simpulan: Konsentrasi Hambat Minimal (KHM) dihasilkan oleh ekstrak dengan konsentrasi 25\% dan zona hambat terbaik dihasilkan oleh ekstrak dengan konsentrasi $100 \%$.
1Program Studi Pendidikan Dokter, Fakultas Kedokteran, Universitas Udayana

${ }^{2}$ Bagian Farmakologi, Fakultas Kedokteran Universitas Udayana

\section{*Korespondensi:}

Anak Agung Bintang Astridwiyanti, Program Studi Pendidikan Dokter, Fakultas Kedokteran, Universitas Udayana

bintangastridwiyanti@gmail.com

Diterima: 05-03-2019

Disetujui: 11-04-2019

Diterbitkan: 01-12-2019
Kata kunci: Kulit buah naga merah (hylocereus polyrhizus), ekstrak etanol, zona hambat, KHM, S.aureus

Cite Pasal Ini: Astridwiyanti, A.A.B., Mahendra, A.N., Dewi, N.W.S. 2019. Uji efektivitas ekstrak etanol kulit buah naga merah (Hylocereus polyrhizus) terhadap Staphylococcus aureus ATCC 25923 secara in vitro. Intisari Sains Medis 10(3): 482-486. D0I: 10.15562/ism.v10i3.425

\section{PENDAHULUAN}

Penyakit infeksi masih menjadi salah satu penyebab utama tingginya angka kesakitan dan kematian di Indonesia yang beriklim tropis. Penyakit infeksi dapat disebabkan oleh mikroba patogen, salah satunya bakteri staphylococcus aureus. ${ }^{1}$
Kematian akibat penyakit infeksi yang meliputi infeksi saluran pernapasan akut, diare, campak, AIDS, malaria dan tuberkulosis mencapai lebih dari $85 \%$ kematian di seluruh dunia. Resistensi terhadap obat lini pertama pada patogen menyebabkan 
persentase kejadian penyakit ini berkisar dari nol sampai hampir 100\%. Dalam beberapa kasus, resistensi terhadap obat lini kedua dan ketiga secara serius merugikan hasil pengobatan. Ditambah lagi infeksi pathogen resisten yang berasal dari rumah sakit (nosocomial infection). ${ }^{2}$

Resistensi bakteri terhadap obat antibiotik merupakan salah satu masalah yang serius, hal ini dapat dibuktikan dari kasus kematian akibat infeksi bakteri resisten tercatat sebanyak 13.300 orang, menurut data Centre for Disease Prevention. Namun, seiring meningkatnya kasus resistensi bakteri ini, tidak diimbangi dengan penemuan antibiotik baru. ${ }^{1}$

S. aureus telah berevolusi seiring perjalanan pemakaian obat antibiotik yang menyebabkan bakteri ini mengalami resistensi terhadap antibiotik yang umumnya digunakan untuk membunuh bakteri ini. Bakteri ini terakhir telah mengalami resisten terhadap methicillin yang dikenal sebagai methicillin-resistant staphylococcus aureus (MRSA). Pada populasi umum diperkirakan MRSA telah menginfeksi sekitar 2-3\% saat ini. Sekitar tahun 1996-1999, sebanyak 23 rumah sakit di Kanada tercatat pathogen $s$. aureus yang resisten terhadap methicillin mencapai 6\%, dengan kasus MRSA per 1000 mencapai rerata 4,14 kasus yang dirawat dari $35 \%$ pasien dengan infeksi. ${ }^{3}$

Mikroorganisme yang tergolong ke dalam gram positif ini menimbulkan angka mortalitas sebanyak 50\% pada kasus staphylococcal scalded skin syndrome (SSSS), serta infeksi sistemik bakteremia stafilokokus dengan angka mortalitas sebanyak $15-60 \%$, peningkatan insiden nonmenstrual toxic shock syndrome sebanyak $40-60 \%$, menstrual toxic shock syndrome sebanyak 95\% dan endokarditis sebanyak $25-35 \%{ }^{3}$

Indonesia memiliki keanekaragaman hayati yang beragam, salah satu jenis tumbuhan kaktus yang belakangan ini sering diperbincangkan di kalangan masyarakat yaitu buah naga. Terdapat beberapa spesies buah naga salah satunya yang terkenal adalah jenis buah naga merah (hylocereus polyrhizus). Meskipun pemanfaatan buah naga masih terbatas pada daging buahnya saja, jika diamati lebih jauh, maka bisa ditemukan banyak potensi besar yang dimiliki oleh bagian lain dari buah naga merah. Salah satu bagian dari buah naga yang dapat dimanfaatkan adalah kulitnya. Bagian dari kulit buah naga adalah 30\%-35\% dari keseluruhan total bagian buah naga, namun seringkali hanya dibuang sebagai sampah. Beberapa penelitian diketahui bahwa kulit buah naga merah memiliki potensi sebagai antibakteri dan antijamur karena mengandung beberapa senyawa aktif seperti alkaloid, terpenoid dan flavonoid. ${ }^{4}$
Pada penelitian lain yang juga menguji kulit buah naga merah, diketahui bahwa terdapat efek antibakteri yang dapat menghambat pertumbuhan bakteri streptococcus mutans dan p. acnes. Kandungan terpenoid dan alkaloid pada kulit buah naga merah diketahui dapat mengganggu aktivitas dinding sel bakteri. ${ }^{4,5}$

\section{BAHAN DAN METODE}

Penelitian ini menggunakan metode true experimental post test only control group design. Uji aktivitas antibakteri yang digunakan adalah disc diffusion (Kirby-Bauer). Zona hambat yang terbentuk pada media agar akan diukur diameternya kemudian dianalisis.

Alat-alat yang dibutuhkan antara lain, inkubator, ose, lampu spritus $500 \mathrm{ml}$, erlenmeyer, autoclave, batang pengaduk, micro pipet, jangka sorong, korek api, kaca preparat, pinset/ penjepit, dan water bath. Bahan-bahan yang digunakan antara lain, kulit buah naga merah, vancomycin $30 \mu \mathrm{g}$, lidi kapas steril, akuades, bakteri staphylococcus aureus, alkohol 95\%, larutan McFarland 0,5, swab kapas steril, blank disc, etanol 96\%, dan agar MuellerHinton (MH) dan cawan petri.

\section{Pembuatan ekstrak kulit buah naga merah}

Buah naga merah sebanyak $25 \mathrm{~kg}$ yang dipanen langsung dari perkebunan diambil kulitnya. Kulit buah kemudian dicuci bersih di air mengalir, kemudian dipotong kecil-kecil dan disortasi basah. Setelah itu keringkan di oven dan blender hingga menjadi serbuk simplisia.

Metode maserasi dimulai dengan merendam simplisia kulit buah naga dengan larutan etanol 96\% sebanyak 6-7 liter selama 3×24 jam, setelah itu dilakukan penyaringan. Hasil penyaringan tersebut ditaruh di rotary vacuum evaporator untuk dipekatkan dengan suhu $60-70^{\circ} \mathrm{C}$ hingga volume hasil ekstraksi berkurang. Setelah itu, hasil evaporasi diuapkan sehingga diperoleh ekstrak kental. yang kemudian diencerkan dengan etanol 96\%.

\section{Pengujian antibakteri ekstrak kulit buah naga merah}

Metode uji yang digunakan yaitu disc diffusion (Kirby-Bauer). Pertama-tama mencelupkan swab kapas yang telah steril ke dalam suspensi bakteri, peras swab kapas dengan memberikan menekan ke dinding tabung suspensi bakteri untuk menghindari cairan yang banyak berpindah ke lempeng uji agar Mueller-Hinton (MH). Selanjutnya swab tersebut diusapkan ke media agar $\mathrm{MH}$ secara merata di seluruh permukaannya dan biarkan biakan bakteri mengering selama 3-5 menit pada suhu ruangan $\left(25^{\circ} \mathrm{C}\right)$. Kemudian teteskan 
ekstrak masing-masing pada setiap paper disc menggunakan micropipette sebesar 20 mikron. Setelah paper disk agak kering, letakkan dalam cawan petri yang sudah berisikan koloni bakteri. Cakram diletakkan di atas media agar dengan menggunakan pinset. Setiap cawan petri yang berukuran diameter $10 \mathrm{~cm}$ diletakkan 6 cakram yang masing-masing mengandung: Vancomycin $(30 \mu \mathrm{g})$, etanol 96\%, ekstrak kulit buah naga merah. Kemudian cawan petri yang telah berisi paper disc tersebut diletakkan di inkubator dengan suhu $37^{\circ} \mathrm{C}(18-24 \mathrm{jam})$.

\section{Analisis data}

Hasil uji aktivitas antibakteri berupa diameter zona hambat yang telah diukur kemudian dianalisis menggunakan bantuan komputer.

\section{HASIL}

Dari hasil pengukuran didapatkan diameter zona hambat yang terbentuk memiliki variasi diameter di setiap pengulangan (tabel 1).

Didapatkan perbandingan lurus antara diameter zona hambat dengan konsentrasi ekstrak, dimana semakin besar konsetrasi ekstrak maka diameter zona hambat staphylococcus aureus ATCC 25923 yang terbentuk juga semakin besar. Rata-rata diameter zona hambat terbesar terdapat pada konsentrasi ekstrak 100\%. Sesuai dengan penelitian yang dilakukan oleh Suhartati, Roziqin dan Wahdaningsih dkk. terhadap streptococcus pyogenes dan propionibacterium acnes, dimana zona hambat terbesar dihasilkan oleh konsentrasi ekstrak terbesar selama percobaan. ${ }^{5,9}$ Ekstrak dengan konsentrasi $25 \%$, terlihat sudah dapat menghambat laju pertumbuhan bakteri dengan membentuk zona hambat yang dikatakan sebagai konsentrasi hambat minimum (KHM).

Hasil uji Mann-Whitney pada tabel 1 didapatkan perbedaan yang bermakna antar setiap kelompok perlakuan, namun antara ekstrak dengan

\section{Tabel 1 Zona Hambat Staphylococcus aureus ATCC 25923 di setiap} kelompok perlakuan

\begin{tabular}{|c|c|c|c|c|c|}
\hline \multirow[b]{2}{*}{ Jenis Perlakuan } & \multicolumn{4}{|c|}{ Diameter zona hambat (mm) } & \multirow{2}{*}{$\begin{array}{c}\text { Rerata } \\
(\mathrm{mm})\end{array}$} \\
\hline & $\mathbf{I}$ & II & III & IV & \\
\hline P1 : ekstrak konsentrasi $25 \%$ & 8 & 9 & 8 & 8 & $8,25^{a} \pm 0,500$ \\
\hline P2 : ekstrak konsentrasi 50\% & 11 & 11 & 11 & 10 & $10,75^{\mathrm{b}} \pm 0,500$ \\
\hline P3 : ekstrak konsentrasi 75\% & 11 & 11 & 11 & 11 & $11^{\mathrm{b}}$ \\
\hline P4 : ekstrak konsentrasi $100 \%$ & 12 & 13 & 13 & 12 & $12,5^{c} \pm 0,577$ \\
\hline $\mathrm{K} 1$ : Vankomisin $30 \mu \mathrm{g}$ & 19 & 19 & 19 & 19 & $19^{d}$ \\
\hline K2 : Etanol 96\% & 0 & 0 & 0 & 0 & $0^{\mathrm{e}}$ \\
\hline
\end{tabular}

Keterangan : Superskrip huruf yang berbeda (a, b, c, d, e) pada kolom yang sama menunjukan perbedaan nyata $(\mathrm{p}<0,05)$ konsentrasi 50\% dan 75\% tidak didaatkan perbedaan yang bermakna.

\section{PEMBAHASAN}

Data hasil pengamatan pada table 1 apabila dibandingkan dengan tabel Greenwood dalam Tammi, didapatkan ekstrak dengan konsentrasi $25 \%$ termasuk dalam kategori tidak memiliki respon dengan rerata diameter zona hambat $8,25 \mathrm{~mm} .{ }^{6}$ Ekstrak dengan konsentrasi $25 \%$ ini memiliki zona hambat yang dikatakan sebagai konsentrasi hambat minimum (KHM), dimana dengan konsentrasi 25\% telah efektif dalam menghambat laju pertumbuhan bakteri. Pada ekstrak dengan konsentrasi 50\%, $75 \%$ dan 100\% menunjukkan rerata diameter zona hambat yang tergolong respon daya hambat lemah.

Penelitian lain yang dilakukan oleh Wahdaningsih dkk. ${ }^{5}$ dengan menggunakan ekstrak kulit buah naga (hylocereus polyrhizus) merah yang difraksinasi menggunakan pelarut $n$-heksana didapatkan aktivitas antibakteri pada propionibacterium acnes, namun zona hambat tidak terbentuk pada bakteri staphylococcus epidermidis di ketiga konsentrasi ekstrak yang diujikan. Perbedaan hasil antara staphylococcus epidermidis dengan staphylococcus aureus ATCC 25923 ini dapat terjadi karena jenis fraksi pelarut yang digunakan berbeda. Pada penelitian Wahdaningsih dkk. ${ }^{5}$ kulit buah diekstraksi dengan metode fraksinasi menggunakan pelarut n-Heksana, sedangkan pada penelitian ini kulit buah diekstraksi menggunakan pelarut etanol $96 \%$.

Etanol 96\% banyak digunakan sebagai pelarut pada ekstraksi senyawa bioaktif karena sifat etanol yang mudah menembus membran sel sehingga baik digunakan untuk mengekstrak senyawa antibakteri seperti tannin, fenol, dan flavonoid. Larutan etanol mampu menarik berbagai senyawa polar dan nonpolar seperti alkaloid, tannin, steroid, saponin, flavonoid dan terpenoid. Sedangkan pada pelarut n-Heksana komponen yang umumya larut adalah senyawa non-polar. ${ }^{7}$ Perbedaan senyawa metabolit yang tertarik antara kedua pelarut tersebut kemungkinan menyebabkan perbedaan hasil respon zona hambat yang didapatkan.

Perbedaan spesies bakteri juga bisa menyebabkan perbedaan hasil, pada penelitian ini spesies bakteri yang di gunakan adalah staphylococcus aureus ATCC 25923, sementara pada penelitian Wahdaningsih dkk. $^{5}$ bakteri yang digunakan adalah Staphylococcus epidermidis. Meski kedua bakteri tersebut sama-sama tergolong bakteri gram positif, namun terdapat perbedaan antara bakteri S.epidermidis dan S.aureus. Bakteri S. epidermidis memerlukan antibakteri yang lebih peka untuk menghambat pertumbuhannya karena bakteri ini 


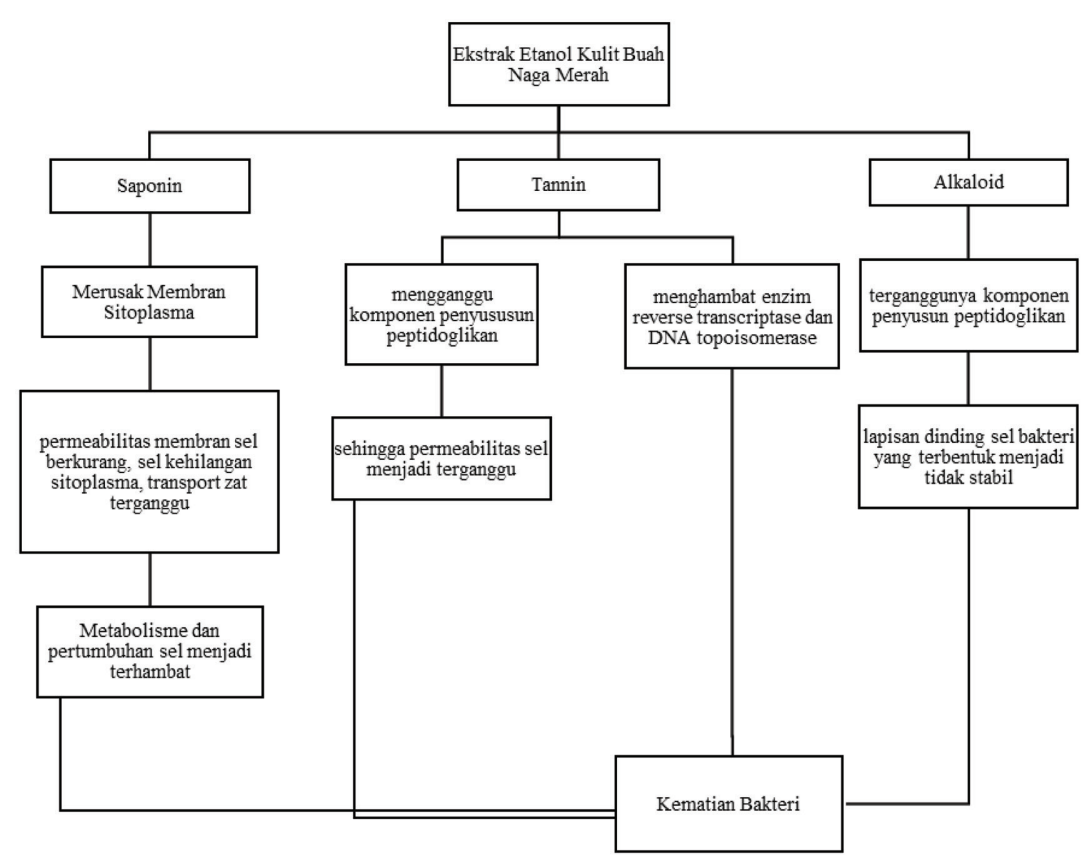

Gambar 1 Bagan ilustrasi mekanisme kerja senyawa metabolit sekunder aktif ekstrak etanol kulit buah naga merah (hylocereus polyrhizus)

merupakan golongan bakteri yang tahan terhadap antibakteri. ${ }^{8}$

Efek antibakteri pada ekstrak etanol kulit buah naga merah, diduga karena terdapat senyawa metabolit sekunder didalamnya, seperti pada penelitian Suhartati dan Roziqin menunjukkan bahwa kandungan yang terdapat pada ekstrak etanol kulit buah naga merah adalah senyawa saponin, tannin, dan alkaloid (Gambar 1). ${ }^{9}$

Saponin merupakan glikosida steroid atau triterpenoid yang ditemukan di berbagai tanaman. Saponin dikenal karena keragaman struktural dan berbagai sifat biologisnya. Senyawa saponin bekerja dengan merusak membran sitoplasma sehingga permeabilitas membran sel menjadi berkurang, sel kehilangan sitoplasma, transport zat terganggu, dan metabolism terhambat. Zat yang terdapat di dalam sel dapat keluar dari sel seperti asam amino, nutrisi dan ion organik enzim, menyebabkan terganggunya pertumbuhan sel bakteri dan pada akhirnya sel mengalami kematian..$^{9,10}$

Tanin bekerja melalui reaksi dengan membran sel dengan mengganggu komponen penyususun peptidoglikan serta menghambat sintesis protein pada dinding sel sehingga permeabilitas sel menjadi terganggu. Efek tannin juga melalui menghambat kerja enzim, dan menghancurkan atau menghambat fungsi materi genetik. Tanin dapat menghambat enzim DNA topoisomerase dan reverse transcriptase yang menyebabkan sel bakteri tidak terbentuk. ${ }^{9}$

Alkaloid menghambat pertumbuhan bakteri dengan cara mengganggu komponen penyusun peptidoglikan pada dinding bakteri, yang menyebabkan dinding sel bakteri menjadi tidak stabil. Alkaloid sebagai antibakteri juga telah diteliti pada alkaloid kelas kelas indolizidine, isoquinoline, uinolone, agelasine dan polyamine. Mekanisme alkaloid yang lain dalam menghambat pertumbuhan bakteri yaitu dengan dengan menghambat kerja enzim dihydrofolate reduktase sehingga sintesa asam nukleat menjadi terhambat. Pada beberapa penelitian menunjukkan aktivitas alkaloid kelas aaptamine, isoquinolone, pyrrolidine and bisindole-imidazole dalam menghambat enzim sortase. ${ }^{11,12}$

\section{SIMPULAN}

Ekstrak Etanol Kulit Buah Naga Merah (hylocereus polyrhizus) memiliki potensi dalam menghambat pertumbuhan bakteri staphylococcus aureus ATCC 25923 dengan rereata diameter zona hambat berkisar antara 8,25 mm sampai $12,5 \mathrm{~mm}$.

Konsentrasi Hambat Minimal (KHM) dihasilkan oleh ekstrak dengan konsentrasi 25\%, sedangkan zona hambat terbesar dihasilkan oleh ekstrak dengan konsentrasi $100 \%$. Terdapat perbedaan yang bermakna masing-masing konsentrasi ekstrak terhadap aktivitas penghambatan pertumbuhan staphylococcus aureus ATCC 25923, namun pada konsentrasi $50 \%$ tidak memiliki perbedaan bermakna dengan konsentrasi $75 \%$.

\section{SARAN}

Perlu dilaksanakan penelitian lebih lanjut mengenai kulit buah naga merah sebagai antibakteri terhadap pertumbuhan bakteri staphylococcus aureus secara in vivo serta penelitian lebih lanjut mengenai efek farmakologis lainnya pada zat aktif spesifik yang terkandung dalam kulit buah naga merah terhadap pertumbuhan bakteri staphylococcus aureus.

\section{ETIKA DALAM PENELITIAN}

Penelitian ini telah mendapat persetujuan dari komite etik dan penelitian Fakultas Kedokteran/ RSUP Sanglah dengan nomer referensi 769/ $\mathrm{UN} 14.2 .2 / \mathrm{PD} / \mathrm{KEP} / 2018$

\section{PENDANAAN}

Penelitian ini tidak mendapatkan dana dari hibah pemerintah ataupun lembaga swasta.

\section{KONFLIK KEPENTINGAN}

Penulis menyatakan tidak terdapat konflik kepentingan dalam penelitian ini 


\section{DAFTAR PUSTAKA}

1. Setiawati A. Peningkatan Resistensi Kultur Bakteri staphylococcus aureus terhadap Amoxicillin Menggunakan Metode Adaptif Gradual. Jurnal Farmasi Indonesia. 2015;7(3):190-194.

2. WHO (World Health Organization). WHO Global Strategy for Containment of Antimicrobial Resistance. 2001.

3. Wirahjasa N. Panji AS. Pengelolaan Infeksi Akibat methicillin resistent staphylococcus aureus. E-Medika Udayana. 2012;2(3):135-143.

4. Hardiana RW. Efektivitas Ekstrak Kulit Buah Naga Merah (hylocereus polyrhizus) terhadap Pertumbuhan streptococcus mutans dan candida albicans (In Vitro) (Skripsi). Jember: Fakultas Kedokteran Gigi Universitas Jember. 2016.

5. Wahdaningsih S, Untari EK, Fauziah Y. Antibakteri Fraksi n-Heksana Kulit hylocereus polyrhizus Terhadap staphylococcus epidermidis dan propionibacterium acnes. Pharm Sci Res. 2014;1(3):180-193.

6. Tammi A. Perbandingan Daya Hambat Ekstrak Daun Salam (syzygium polyanthum [Wight.] Walp.) Terhadap Pertumbuhan Bakteri staphylococcus aureus dan Escherichia coli secara In Vitro (Skripsi). Bandar Lampung: Fakultas Kedokteran Universitas Lampung. 2016.
7. Zakaria S, Syah NH, Firdaus YM. Aktivitas Antibakteri Dari Fraksi Artocarpus Integer (Thunb.) Merr. Dengan Metode Difusi Agar. Jurnal Industri Hasil Perkebunan. 2017;12(2):1-6.

8. Jawetz E, Melnick JL, Adelberg EA, editor. Mikrobiologi Kedokteran: Edisi XXII. Jakarta: Salemba Medika. 2001.

9. Suhartati R, Roziqin DA. Aktivitas Antibakteri Ekstrak Etanol Kulit Buah Naga Merah (hylocereus polyrhizus) Terhadap Bakteri streptococcus pyogenes. Jurnal Kesehatan Bakti Tunas Husada. 2017;17(2):513-518.

10. Tortora GJ, Funke GR, Case CL. Microbiology: edisi ke-9. San Francisco: Pearson Education. 2007.

11. Cushnie TPT, Cushnie B, Lamb AJ. Alkaloids: An overview of their antibacterial, antibiotic-enhancing and antivirulence activities. International Journal of Antimicrobial Agents. 2014;44:377-386.

12. Tandio D, Manuaba A. Safety Procedure for Biosafety and Controlling a Communicable Disease: Streptococcus Suis. Bali Medical Journal. 2016;5(2): 260-262. DOI:10.15562/ bmj.v5i2.220.

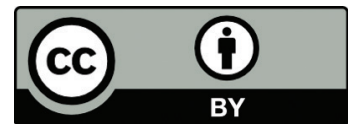

This work is licensed under a Creative Commons Attribution 